\title{
PERUBAHAN PERILAKU AKTIVITAS SEKSUAL PADA PENDERITA STROKE
}

\author{
Wawan Ridwan Mutaqin \\ Dosen Poltekkes Kemenkes Surakarta Jurusan Okupasi Terapi \\ Email: abiroyyan_naufal@yahoo.co.id
}

\begin{abstract}
Abstrack: Change of Sexual Behavior Activities in Stroke Patients. Sex is a human need, not only in normal individuals, but also in patients with stroke. Sexuality is one aspect of the complex on the individual human being. Strokes can cause changes in sexual behavior, either lowered libido, sexual potency and sexual satisfaction. This research is descriptive qualitative field that aims to identify changes in the behavior of sexual activity in patients with stroke. The research strategy is a case study stuck (embedded case study research). The data analysis was done through descriptive analysis. Sources of research data: (1) the informant or informants from the patient, his wife, and children, (2) records and documents regarding the patient's status. Data was collected by means of in-depth interviews (deep interview) and focus groups (focus group discussion). Based on the results showed the themes of sexual activity behavior is the marital relationship / marital relations, negative self-concept, sexual function limitation, the factors that encourage sexual activity, sexual function, desire to serve and to stop sexual intercourse. Changes in sexual activity behavior stroke patients affected by the condition of the patient, who is believed religion and culture.
\end{abstract}

Keywords: Change behavior, Sexual activity, Stroke

\begin{abstract}
Abstrak: Perubahan Perilaku Aktivitas Seksual pada Penderita Stroke. Seks adalah salah satu kebutuhan manusia, tidak hanya pada orang normal tetapi juga pada penderita stroke. Seksualitas merupakan salah satu aspek kompleks pada individu manusia. Stroke dapat menyebabkan perubahan perilaku seksual, baik menurunkan libido, potensi seksual dan kepuasan seksual. Penelitian ini merupakan penelitian lapangan yang bersifat deskriptif kualitatif yang bertujuan untuk mengetahui perubahan perilaku aktivitas seksual pada penderita stroke. Strategi penelitian yang digunakan adalah studi kasus terpancang (embedded case study research). Analisis data dilakukan melalui analisis deskritif. Sumber data penelitian berupa: (1) informan atau narasumber dari pasien, istri, dan anak, (2) arsip dan dokumen mengenai status pasien. Tehnik pengumpulan data dilakukan dengan cara interview mendalam (deep interview) dan diskusi kelompok terfokus (focus group discussion). Berdasarkan hasil analisis data penelitian diperoleh tema-tema perilaku aktivitas seksual adalah hubungan suami istri/ bersetubuh, konsep diri negatif, keterbatasan fungsi seksual, faktor-faktor yang mendorong aktifitas seksual, fungsi seksual, hasrat untuk mengabdi dan berhenti melakukan hubungan seksual. Perubahan perilaku aktifitas seksual penderita stroke dipengaruhi oleh kondisi penderita, agama yang diyakini dan budaya.
\end{abstract}

Kata Kunci: Perubahan Perilaku, Aktivitas Seksual, Stroke

Cerebrovaskuler atau stroke termasuk salah satu penyakit neurologis akibat gangguan edar darah di otak. Stroke dapat menimbulkan kecacatan yang meliputi impairment, disability dan handicap. Kondisi tersebut mengakibatkan penderita mengalami kesulitan atau bahkan tidak mampu melakukan aktivitasnya sehari-hari.

Riset Kesehatan Dasar (Riskesdas) tahun 2007 berhasil mendata kasus stroke di wilayah perkotaan di 33 provinsi dan 440 kabupaten. Riskesdas tahun 2007 ini berhasil mengumpulkan sebanyak 258.366 sampel rumah tangga perkotaan dan 987.205 sampel anggota rumah tangga untuk pengukuran berbagai variabel kesehatan masyarakat. Hasilnya, stroke merupakan pembunuh utama di antara penyakitpenyakit noninfeksi di kalangan penduduk perkotaan (Asosiasi Herbalis Nusantara, 2011).

Seks adalah salah satu kebutuhan manusia, tidak hanya pada orang normal tetapi juga pada penderita stroke. Seksualitas merupakan salah satu aspek kompleks pada individu manusia. Ekspresi seksual tergantung dari sistem anatomi dan fisiologi, serta dipengaruhi faktor fisik dan psikis. Beberapa literatur dan penelitian menyatakan bahwa stroke menyebabkan perubahan perilaku seksual, baik menurunkan libido, potensi seksual dan kepuasan seksual. Penderita pria dan wanita ragu untuk melanjutkan aktivitas seksual pasca stroke, karena takut 
bahwa akan menyebabkan suatu serangan stroke lagi. Penurunan aktivitas seksual bagi penderita dan pasangannya berpengaruh pada keharmonisan perkawinan karena kebutuhan seksualnya tidak terpenuhi.

\section{METODE PENELITIAN}

Penelitian ini merupakan penelitian kualitatif dengan strategi penelitian yang digunakan adalah studi kasus terpancang (embedded case study research). Analisis data dilakukan melalui analisis deskritif. Sumber data penelitian berupa : (1) informan atau narasumber dari pasien, istri, dan anak, (2) arsip dan dokumen mengenai status pasien. Tehnik pengumpulan data dilakukan dengan cara interview mendalam (deep interview) dan diskusi kelompok terfokus (focus group discussion). Tehnik sampling yang akan digunakan dalam penelitian ini adalah purposive sampling. Penelitian dilakukan di Wilayah Kecamatan Ngemplak, Kabupaten Boyolali.

\section{HASIL}

\section{Gambaran Umum Partisipan}

Partisipan pertama. Seorang laki-laki berinisial Tn. Sp. usia 55 tahun, beragama Islam, diagnosis stroke hemiparesis sinistra, dan pendidikan terakhir sekolah dasar. Sebelum terkena stroke, partisipan bekerja sebagai pembuat sumur bor dan setelah terkena stroke belum bekerja kembali. Sekarang partisipan hidup bersama 4 orang anak, istri dan satu menantunya. Partisipan ini telah mengalami stroke 1,5 tahun dan sudah mampu melakukan mobilitas menggunakan tripod. Aktifitas kesehariannya lebih banyak tergantung pada orang lain terutama pada istri dan anaknya. Menurut para tetangga dan keluarganya, sebelum sakit dia sangat rajin mengikuti kegiatan ibadah dan keagamaan, seperti pengajian, yasinan dan perayaan keagamaan lainnya. Namun sekarang karena mobilitasnya terganggu dan kurangnya fasilitas yang tersedia maka aktifitas tersebut tidak pernah lagi dilakukan dan hanya beribadah di rumah saja.

Partisipan kedua. Berinisial Ny. Sy. berusia 46 tahun, beragama Islam, dan pendidikan sekolah menengah pertama. Partisipan tinggal bersama 4 orang anak, suami dan ibunya. Partisipan ini telah mengalami stroke hemiparesis sinistra selama 10 tahun. Partisipan sudah melakukan berbagai upaya untuk penyembuhan penyakitnya, baik medis maupun non medis seperti pengobatan alternatif tradisional. Sebelum menderita stroke, partisipan bekerja di sebagai karyawan pabrik percetakan dan aktif dalam berbagai kegiatan keagamaan dan kemasyarakatan. Sekarang masih bisa mengikuti kegiatan keagamaan tetapi lokasinya tidak jauh dari rumahnya. Partisipan dapat berjalan tanpa alat bantu, tetapi pola jalan dengan gerakan kompensasi. Sekarang tidak bekerja dan mampu melakukan aktifitas sehari-hari secara mandiri.

Partisipan ketiga. Berinisial Tn. Sm, beragama Islam, berusia 53 tahun, pendidikan sarjana, bekerja sebagai guru. Partisipan tinggal bersama dengan 2 orang anak dan istrinya. Tn. Sm mengalami stroke hemiparesis dekstra sekitar 13 tahun. Saat ini partisipan sudah mampu berjalan tanpa alat bantu dan sudah bekerja kembali sebagai guru agama meskipun hanya dilakukan seminggu 2 kali. Sebelum sakit Tn. Sm rajin beribadah, ikut berpartisipasi dalam kegiatan keagamaan dan kemasyarakatan, bahkan sering memberikan tausiah. Sekarang Tn. Sm merasa tidak dapat berpartisipasi dalam kegiatan keagamaan dan kemasyarakatan akibat stroke yang dideritanya. Ibadah dilakukan di rumahnya.

Partisipan keempat. Berinisial Tn. Zuh, berusia 70 tahun, beragama Islam, pensiunan AURI, pendidikan sekolah menengah atas, tinggal bersama anak dan istrinya. Partisipan menderita stroke hemiparesis sinistra sekitar 2 tahun yang lalu akibat diabetus mellitus. Tn. Zuh. dapat berjalan tetapi dengan pola jalan yang abnormal. Pernah berobat ke dokter dan menjalani rawat inap di rumah sakit, tetapi karena merasa belum sembuh juga kini hanya berobat alternatif tradisional. Aktifitas sehari-hari dilakukan secara mandiri. Kegiatan sehariharinya hanya dihabiskan untuk ngobrol dengan tetangga terdekat dan menonton televisi.

Partisipan kelima. Berinisial Ny. Smm. berusia 46 tahun, beragama Islam, pendidikan sekolah dasar. Dia tinggal bersama suami dan 2 orang anaknya. Partisipan mengalami stroke hemiparesis sinistra sekitar 5 tahun yang lalu. Partisipan pernah menjalani rawat inap di rumah sakit selama 2 minggu, sejak pertama sakit sampai sekarang Ny. Smm. dengan dukungan penuh keluarga semangat untuk berobat baik secara medis ataupun dengan pengobatan alternatif tradisional. Sebelum sakit partisipan bekerja sebagai pedagang buah di pasar, rajin beribadah dan mengikuti kegiatan di desanya. Sekarang pasien dapat berjalan dan masih aktif mengikuti pengajian. 


\section{Pelaksanaan}

Pelaksanaan penelitian merupakan rangkaian pengumpulan dan pengolahan data. Pelaksanaan penelitian tersebut dapat dibagi menjadi dua bagian yaitu wawancara pertama dan wawancara kedua.

Wawancara pertama. Kegiatan ini merupakan rangkaian pengumpulan data-data awal yang diambil oleh peneliti. Peneliti secara langsung terjun ke daerah partisipan dan melakukan wawancara yang mendalam kepada mereka. Naskah pertanyaan dibuat pada saat pembuatan proposal, sifat pertanyaan yang diberikan adalah terbuka. Dari wawancara pertama ini didapatkan hasil penelitian yang bersifat sementara, karena tema-tema yang muncul belum teruji keabsahannya. Untuk hal itu maka dilakukan uji credibility dengan mengacu pada hasil wawancara pertama.

Wawancara kedua. Kegiatan ini merupakan uji credibility dari hasil wawancara pertama. Hal tersebut dimaksudkan agar datadata awal yang telah dikumpulkan agar menjadi valid dan reliabel. Pelaksanaannya dengan melakukan wawancara ulang kepada partisipan.

\section{Hasil Penelitian}

Data yang terkumpul kemudian dianalisis data dalam penelitian ini dilakukan dalam beberapa tahap. Selanjutnya tahapan tersebut akan dijelaskan sebagai berikut.

Langkah 1. Setelah peneliti mengumpulkan data-data melalui wawancara mendalam, selanjutnya peneliti melakukan review kembali hasil-hasil wawancara. Peneliti membaca dengan tekun dan cermat terhadap hasil-hasil yang telah didapat.

Langkah 2. Data-data yang dikumpulkan pada wawancara pertama hasilnya dilihat kembali untuk menentukan beberapa kategori. Penentuan kategori ini hanya berdasarkan interpretasi dari peneliti yang disesuaikan dengan pertanyaan yang diberikan, selanjutnya akan menjadi dasar acuan untuk melakukan wawancara kedua.

Langkah 3. Peneliti melakukan penyempurnaan kategori yang ditentukan tadi. Peneliti melakukan wawancara kedua kepada partisipan. Selanjutnya hasil-hasil tersebut ditentukan kategori lagi, kategori tersebut merupakan hasil dalam penelitian ini. Adapun kategori-kategori tersebut dijelaskan pada beberapa tabel 1 .

Tabel 1. Analisis data perilaku aktifitas seksual partisipan

\begin{tabular}{lll}
\hline \multicolumn{1}{c}{ Kategori } & \multicolumn{1}{c}{ Definisi } & \multicolumn{1}{c}{ Penjelasan } \\
\hline Hubungan suami istri / & Aktivitas yang berhubungan "Kalo saya aktifitas seksual itu ya \\
bersetubuh & dengan organ-organ seks dan hubungan suami istri", "Meniko \\
memperoleh kenikmatan darinya & aktifitas campur (itu aktifitas \\
& & bersetubuh)", "Menurut saya yaitu \\
hubungan suami istri", "Ya \\
bersetubuh pak".
\end{tabular}

Konsep diri negatif Konsep diri negatif adalah perasaan para penderita stroke terhadap keadaan dirinya yang merasa lemah atau tidak berguna.

Keterbatasan fungsi Keterbatasan fungsi merupakan seksual

Faktor-faktor yang mempengaruhi aktivitas seksual : 1. Faktor fisik ketidakmampuan untuk melakukan aktifitas seksual.

Faktor fisik yang berperan adalah neuromuskular dan umur.
"Nggih mpun mas sudah sepuh (sudah tua)", "Kalo sudah gini ini ya saya kira sudah lemah", "Ya tidak, wong saya sudah merasa tua, apalagi saya sudah tidak mens lagi”.

"Nggih boten bahasane nggih boten kados manusia normallah (ya tidak bahasanya, ya tidak seperti manusia normallah), nggih niku kan niki dereng bisa (ya itu, kan belum bisa)... badan saya belum bisa... ya gerak seperlunya... yang ada cuma'... belum maksimallah", "Agak sulit.. karna tubuhnya ini ya sudah lemah"

"Nggih mpun mas sudah sepuh (Ya pembuluh darah, hormonal, sudah mas sudah tua), ya ini ya anu... ya agak mengendor sedikitlah", "Soyo anu (semakin)... 
2. Faktor Budaya

3. Faktor psikis

Fungsi seksual:

1. Dorongan (libido)

seks

Bentuk perilaku instingtif secara genetik terprogram dan tersimpan dalam sistem limbik dan hipotalamus

Meliputi perasaan seperti rasa cemas, malu, depresi dan konflik dalam hubungan pribadi

\section{pandangan seksual berdasarkan} pengaruh dari masyarakat melalui hukum, tabu, keluarga dan teman.

kados-kados mboten wonten gairah (sepertinya tidak ada gairah), "kalo sudah gini ini ya saya kira sudah lemah", "mpun mboten saged ngadeg mas (sudah tidak bisa berdiri/ereksi mas)"...

"Saya... semenjak dulu yang minta ya...selalu saya, menawi nopo niku posisine kulo ten nginggil (kalau apa itu posisinya saya di atas), tapio sekarang kalau anu nggak pake foreplay, "Ya posisi masih biasa di bawah"

"Perasaan takut insya Allah tidak", "Kan takut kalau sampai hamil saya kan masih subur", "Kalau sudah hubungan itu ada rasa nyeri saat kencing, dan kencingnya jadi sedikit", "Takut ndak... kalau kaku ya setelah anu itu.. setelah rampung itu... atau jadi pernafasan ngosngosan... kalo sudah timbul nafsu disitu".

"Ya.. normal disentuh masih terangsang", "Malah ada lho penelitian, untuk sehat itu dengan melakukan hubungan seminggu dua kali, malah ada yang bisa menurunkan tensi atau menurunkan kaku-kaku, yang penting santai bu, jangan lupa pemanasannya supaya pelumasnya banyak, ndak sakit"

2. Rangsangan (arousal)

3. Orgasme

4. Tingkat kepuasan
Meningkatnya reaksi seksual terhadap rangsangan seksual yang diterima

Kenikmatan seksual yang merupakan puncak reaksi seksual

"Masih, masih bisa greng (ereksi), masih 100\%", "Ya bisa terangsang... hampir, sekarang, terkadang hanya... lama sekali terangsangnya", "Ya berdirinya berkurang... tapi kalo pagi gitu bisa",

"Iya mengalami kepuasan, tapi sekarang agak beda, lebih lama", "Kalau puas rasanya nikmat dan plong gitu... tapi sekarang agak sulit.. karna tubuhnya ini ya sudah lemah", "Tidak merasakan nikmat, Mungkin rasa takut itu karena nanti kalau kencing akan merasa sakit, jadi tidak merasakan kenikmatan".

Sensasi erotik yang tercapai "Sak niki mpun sudo katah mas" ketika mencapai ejakulasi (sekarang sudah turun banyak mas), ditambah dengan kesenangan "Sak niki mpun mboten saget puas 
psikis

5. Frekuensi seksual

Jumlah melakukan hubungan seksual dalam satu bulan

Yang paling banyak mengambil peran dalam hubungan seksual

Posisi tubuh penderita stroke saat melakukan hubungan seksual

mas, lha mpun mboten saged ngadeg" (sekarang sudah ndak bisa mas, sudah tidak bisa berdiri), "masih bisa menikmati tapi ya... sudah banyak berkurang mas", "biasa aja mas"

"Niku mpun radi kendo" (itu sudah berkurang), "hehe...niku mpun sudo" (itu sudah berkurang), "wah...niku sudo katah sanget mas, riyin sesasih saget ping setunggal, saniki mungkin tigang wulan sepindah sok-sok" (wah...itu berkurang banyak mas, dulu sebulan bisa sekali, sekarang tiga bulan sekali kadang-kadang), "sak niki mpun mboten" (sekarang sudah tidak).

"Njeh kulo" (ya saya), "Kat riyin kulo mas " (dari dulu saya mas), "njeh bapake" (ya bapaknya).

"Kulo biasane teng duwur, tapi sak niki teng andap (saya biasanya di atas, tapi sekarang di bawah), "Kulo teng andap terus mas" (saya di bawah), "Saya ya gentian di bawah", "Kulo manut mawon mas" (saya ikut aja mas).

Hasrat untuk mengabdi

1. Pengabdian kepada pasangan

Penderita stroke akan berusaha memenuhi kewajiban kepada pasangannya

"Yo saya, saya kan ingin memberi nafkah batin istri", "Ya bapak, saya tidak pernah, saya hanya melayani saja."

2. Pengabdian kepada Tuhan

Para penderita stroke "Ya.. istri itukan pakaian suami... berkeinginan untuk terus jadi ya harus bisa dipakai...itukan beribadah kepada Allah SWT, kata agama he...he... Ya... selain untuk meningkatkan derajat ibadah kepada Allah, juga ibadah imannya. kepada suami... melayani suami."

\begin{tabular}{llrl}
$\begin{array}{l}\text { Berhenti melakukan } \\
\text { hubungan seksual }\end{array}$ & $\begin{array}{l}\text { Tidak melakukan hubungan } \\
\text { aktivitas } \\
\text { pasangannya }\end{array}$ & $\begin{array}{l}\text { "Mpun mboten saged mas... mpun } \\
\text { dengan }\end{array}$ & $\begin{array}{l}\text { mboten saged ngadeg" (sudah tidak } \\
\text { bisa mas, sudah tidak bisa berdiri) }\end{array}$ \\
\hline
\end{tabular}

Langkah 4. Analisis kategori aktivitas seksual, pada bagian ini peneliti menguraikan kategori-kategori yang telah didefinisikan tadi.

Hubungan suami istri/ bersetubuh. Setiap aktivitas yang berhubungan dengan organorgan seks dan memperoleh kenikmatan darinya bisa disebut sebagai aktivitas seksual. Aktivitas seksual merupakan bagian integral dari kepribadian yang tidak dapat dipisahkan dari kehidupan manusia, dan merupakan ekspresi dan pengalaman diri sebagai makhluk seksual. Pada dasarnya aktivitas seksual tidak terbatas hanya di tempat tidur atau bagian tubuh saja, tetapi merupakan ekspresi kepribadian, perasaan fisik dan simbolik tentang kemesraan, menghargai dan saling memperhatikan secara timbal balik. Aktivitas seksual seseorang sangat ditentukan 
oleh berbagai kebutuhan, antara lain kebutuhan akan kasih sayang, rasa aman psikologis, serta harga diri sebagai wanita atau pria. Tetapi dalam penelitian ini aktivitas mengalami penyempitan makna, yaitu hubungan suami istri atau bersetubuh. Hal ini sesuai dengan pernyataan partisipan berikut:

"Kalo saya aktifitas seksual itu ya hubungan suami istri" (CHW 1), "Meniko aktifitas campur (itu aktifitas bersetubuh) (CHW 2), "Menurut saya yaitu hubungan suami istri" (CHW 3), "Ya bersetubuh pak". (CHW 6).

Konsep diri negatif. Dampak yang biasanya dirasakan oleh para penderita stroke antara lain konsep diri negatif dan keterbatasan fungsi seksual. Konsep diri negatif merupakan keyakinan, pandangan atau penilaian negatif seseorang terhadap dirinya. Seseorang memandang bahwa dirinya lemah, tidak berdaya, tidak dapat berbuat apa-apa, tidak kompeten, gagal, malang, tidak menarik, tidak disukai dan kehilangan daya tarik terhadap hidup. Sehingga konsep diri negatif menyebabkan penderita merasa lemah, sudah tua dan tidak berguna seperti terlihat pada pernyataan partisipan berikut:

"Nggih mpun mas sudah sepuh (sudah tua)" (CHW 1), "Kalo sudah gini ini ya saya kira sudah lemah" (CHW 3), "Ya tidak, wong saya sudah merasa tua, apalagi saya sudah tidak mens lagi" (CHW 6).

\section{Keterbatasan fungsi seksual. Keterbatasan fungsi seksual merupakan ketidakmampuan untuk melakukan aktifitas seksual yang disebabkan oleh malfungsi dari organ tubuh, seperti tidak berfungsi sebagai mana biasanya atau normal dan adanya kelemahan pada tubuh. Hal ini sesuai ungkapan partisipan} berikut:

"Nggih boten bahasane nggih boten kados manusia normallah (ya tidak bahasanya, ya tidak seperti manusia normallah), nggih niku kan niki dereng bisa (ya itu, kan belum bisa)...badan saya belum bisa...ya gerak seperlunya... yang ada cuma'... belum maksimallah." (CHW 1), "Agak sulit..karena tubuhnya ini ya sudah lemah" (CHW 3).

Faktor-faktor yang mempengaruhi aktifitas seksual. Faktor fisik, mempunyai peranan yang sangat penting dalam aktifitas seksual. Faktor fisik yang berperan adalah pembuluh darah, hormonal, neuromuskular dan umur. Jika kondisi fisiknya dalam arti kesehatannya terganggu, seseorang kemungkinan besar akan mengalami gangguan pemenuhan kebutuhan seksualitasnya, yang dapat ditampilkan melalui berbagai aktivitas seksual. Seperti gangguan gerak, penurunan hormon yang menyebabkan menurunnya gairah seksual. Hal ini diungkapkan partisipan sebagai berikut:

"Nggih mpun mas sudah sepuh (Ya sudah mas sudah tua), ya ini ya anu... ya agak mengendor sedikitlah... (CHW 1). Soyo anu (semakin)... kados-kados mboten wonten gairah (sepertinya tidak ada gairah) (CWH 2), "kalo sudah gini ini ya saya kira sudah lemah..(CHW 3), "mpun mboten saged ngadeg mas (sudah tidak bisa berdiri/ereksi mas)"... (CHW 4).

Faktor budaya, termasuk pandangan masyarakat tentang seksualitas dapat mempengaruhi individu. Tiap budaya mempunyai norma-norma tertentu tentang identitas dan aktivitas seksual. Budaya turut menentukan lama hubungan seksual, cara stimulasi seksual, dan hal lain yang terkait dengan kegiatan seksual. Pada kelompok etnis tertentu, wanita diharapkan untuk bersikap pasif dalam aktivitas seksualnya, sementara pada kelompok etnis yang lain, peran aktif wanita sangat dianjurkan. Dalam penelitian ini penderita pria lebih aktif daripada perempuan, termasuk mengemukakan hasrat dan posisi dalam aktifitas seksual. Hal ini berdasarkan persepsi partisipan berikut:

"Saya... semenjak dulu yang minta ya... selalu saya, menawi nopo niku posisine kulo ten nginggil (kalau apa itu posisinya saya di atas) (CHW 1), tapio sekarang kalau anu nggak pake foreplay (CHW 3), Ya posisi masih biasa di bawah (CHW 6)."

Faktor psikis, sangat penting dalam melakukan aktifitas seksual. Faktor psikis meliputi perasaan seperti rasa cemas, malu, depresi dan konflik dalam hubungan pribadi. Penderita dengan psikis yang baik tidak akan takut melakukan aktifitas seksual, sebaliknya takut atau cemas jika terjadi sesuatu seperti takut hamil, nyeri, capai dan kekakuan. Hal ini diungkapkan partisipan sebagai berikut:

"Perasaan takut insya Allah tidak" (CHW 1), "Kan takut kalau sampai hamil saya kan masih subur" (CHW 2), "Kalau sudah hubungan itu ada rasa nyeri saat kencing, dan kencingnya jadi sedikit." (CHW 6), Takut ndak... kalau kaku ya setelah anu itu.. setelah rampung itu... atau jadi 
pernafasan ngos-ngosan... kalo sudah timbul nafsu disitu (CHW 3)

Fungsi seksual. Dorongan seks (libido), merupakan bentuk perilaku instingtif secara genetik terprogram dan tersimpan dalam sistem limbik dan hipotalamus. Dorongan seksual mutlak diperlukan, karena dialah energi awal yang membangkitkan fungsi seksual. Tanpanya, fungsi seksual tidak dapat berlangsung. Pada penderita stroke, sentuhan, rangsangan dan pemanasan (foreplay) yang cukup dapat meningkatkan dorongan seksual seperti ungkapan partisipan berikut:

"Ya..normal disentuh masih terangsang (CHW 1), Malah ada lho penelitian, untuk sehat itu dengan melakukan hubungan seminggu dua kali, malah ada yang bisa menurunkan tensi atau menurunkan kakukaku, yang penting santai bu, jangan lupa pemanasannya supaya pelumasnya banyak, ndak sakit" (CHW 6)

\section{Rangsangan (arousal), adalah meningkatnya reaksi seksual terhadap rangsangan seksual yang diterima. Manifestasi rangsangan pada pria berupa ereksi dan pada wanita berupa lendir vagina. Rangsangan pada penderita stroke dalam penelitian ini masih berfungsi dengan baik, tetapi kadang membutuhkan waktu yang lama. Hal ini diungkapkan partisipan sebagai berikut: \\ "Masih, masih bisa greng (ereksi), masih $100 \%$ (CHW 1), Ya bisa terangsang)... hampir, sekarang, terkadang hanya... lama sekali terangsangnya (CHW 2), "ya berdirinya berkurang... tapi kalo pagi gitu bisa... (CHW 3)."}

Orgasme, merupakan kenikmatan seksual yang merupakan puncak reaksi seksual. Puncak reaksi seksual tercapai bila menerima rangsangan seksual yang efektif. Jika orgasme tercapai akan dirasakan suatu sensasi erotik yang menyenangkan.

"Iya mengalami kepuasan, tapi sekarang agak beda, lebih lama (CHW 2), "Kalau puas rasanya nikmat dan plong gitu...tapi sekarang agak sulit.. karna tubuhnya ini ya sudah lemah (CHW 3), "Tidak merasakan nikmat, Mungkin rasa takut itu karena nanti kalau kencing akan merasa sakit, jadi tidak merasakan kenikmatan" (CHW 6).

Tingkat kepuasan, merupakan sensasi erotik yang tercapai ketika mencapai ejakulasi ditambah dengan kesenangan psikis. Pada penderita stroke terjadi penurunan kepuasan seksual, hal ini terlihat dari ungkapan partisipan berikut:

"Sak niki mpun sudo katah mas" (sekarang sudah turun banyak mas) (CHW 1), "Sak niki mpun mboten saget puas mas, lha mpun mboten saged ngadeg" (sekarang sudah ndak bisa mas, sudah tidak bisa berdiri) (CHW 4), "masih bisa menikmati tapi ya...sudah banyak berkurang mas" (CHW 5), "biasa aja mas" (CHW 6).

Frekuensi seksual, adalah jumlah melakukan hubungan seksual dalam satu bulan. Pada penderita stroke, frekuensi seksual dapat terjadi penurunan dibandingkan sebelum terkena stroke. Seperti sebelum terkena stroke, penderita melakukan hubungan bisa satu bulan sekali, tetapi setelah terkena stroke menjadi berkurang, bahkan tidakm sama sekali. Hal tersebut dapat dilihat dari ungkapan partisipan sebagai berikut: "niku mpun radi kendo" (itu sudah berkurang) (CHW 1) hehe...niku mpun sudo" (itu sudah berkurang) (CHW 3), "wah...niku sudo katah sanget mas, riyin sesasih saget ping setunggal, saniki mungkin tigang wulan sepindah sok-sok" (wah...itu berkurang banyak mas, dulu sebulan bisa sekali, sekarang tiga bulan sekali kadang-kadang) (CHW 2), "sak niki mpun mboten" (sekarang sudah tidak) CHW 4).

Dominasi hubungan, adalah siapa yang paling banyak mengambil peran dalam hubungan seksual. Dalam penelitian ini terungkap bahwa hubungan seksual masih didominasi oleh kaum pria, dimana penderita stroke pria lebih sering mempunyai inisiatif melakukan hubungan. Seperti ungkapan partisipan berikut:

"Njeh kulo" (ya saya) (CHW 1), "Kat riyin kulo mas " (dari dulu saya mas) (CHW 3), "njeh bapake" (ya bapaknya) (CHW 2)

Posisi hubungan, adalah posisi tubuh penderita stroke saat melakukan hubungan seksual. Posisi yang sering dipilih oleh penderita stroke adalah di bawah atau di atas, dan pada penderita pria, stroke memberikan andil untuk merubah posisi dimana sebelum stroke biasa di atas, pada sebagian menjadi di bawah dan sebagaian lain di atas. Tetapi pada penderita stroke wanita, tidak mengalami perubahan, yaitu tetap di bawah. Berikut ungkapan partisipan:

"Kulo biasane teng duwur, tapi sak niki teng andap (saya biasanya di atas, tapi sekarang di bawah) (CHW 1), "Kulo teng 
andap terus mas" (saya di bawah) (CHW 2). "Saya ya gentian di bawah" (CHW 3), "Kulo manut mawon mas" (saya ikut aja mas) (CHW 5)

Hasrat untuk mengabdi. Tujuan hidup para penderita stroke adalah hasrat untuk mengabdi sebagai wujud mengaktualisasikan dirinya lewat pengabdian kepada pasangan dan dan Allah SWT.

Pengabdian kepada pasangan, para penderita stroke masih mempunyai keinginan untuk memberikan kontribusi sebagai bentuk memenuhi tanggung jawab kepada pasangannya. Penderita stroke mengaku ingin melayani pasangannya. Pernyataan pendukung hal tersebut sebagai berikut:

"Yo saya, saya kan ingin memberi nafkah batin istri (CHW 3), "Ya bapak, saya tidak pernah, saya hanya melayani saja." (CHW 6)

Pengabdian kepada Tuhan, Kehidupan manusia tidak bisa dipisahkan dari agamanya. Agama menyuruh kita menjalankan perintah Tuhan dan menjauhi perbuatan yang dilarang agama Islam. Para penderita stroke berkeinginan untuk terus beribadah kepada Allah SWT dengan menjalankan perintah Nya. Sesuai dengan ungkapan partisipan berikut ini:

"Ya...istri itukan pakaian suami...jadi ya harus bisa dipakai...itukan kata agama he...he....(CHW 6). Ya...selain ibadah kepada Allah, juga ibadah kepada suami....melayani suami (CHW 6)."

Berhenti melakukan hubungan. Dalam penelitian ini, satu penderita berhenti atau tidak melakukan aktifitas seksual setelah terkena stroke karena ketidakmampuan ereksi. Berikut ungkapan partisipan:

"mpun mboten saged mas...mpun mboten saged ngadeg" (sudah tidak bisa mas, sudah tidak bisa berdiri) (CHW 4)

\section{PEMBAHASAN}

\section{Hubungan Suami Istri/ Bersetubuh}

Hasil penelitian menunjukkan bahwa pengertian aktivitas seksual mengalami penyempitan makna, yaitu hubungan suami istri atau bersetubuh. Hal ini sesuai dengan pendapatnya Hafidz (2006) bahwa setiap aktivitas yang berhubungan dengan organ-organ seks dan memperoleh kenikmatan darinya bisa disebut sebagai aktivitas seksual. Aktivitas seksual merupakan bagian integral dari kepribadian yang tidak dapat dipisahkan dari kehidupan manusia, dan merupakan ekspresi dan pengalaman diri sebagai makhluk seksual.

Hasil penelitian ini berbeda dengan pendapatnya Pangkahila, (2001) yang menyatakan bahwa aktivitas seksual merupakan seluruh komponen yang bisa mempengaruhi kehidupan seksualitas seorang individu. Aktivitas seksual bersifat total, multi-determined dan multi dimensi. Oleh karena itu aktivitas seksual bersifat holistik yang melibatkan aspek biopsikososial, kultural, dan spiritual. Pada dasarnya aktivitas seksual tidak terbatas hanya di tempat tidur atau bagian tubuh saja, tetapi merupakan ekspresi kepribadian, perasaan fisik dan simbolik tentang kemesraan, menghargai dan saling memperhatikan secara timbal balik. Aktivitas seksual seseorang sangat ditentukan oleh berbagai kebutuhan, antara lain kebutuhan akan kasih sayang, rasa aman psikologis, serta harga diri sebagai wanita atau pria. Pada kondisi dimana kesehatannya terganggu, seseorang kemungkinan besar akan mengalami gangguan pemenuhan kebutuhan seksualitasnya, yang dapat ditampilkan melalui berbagai aktivitas seksual (Birkhead, 1989).

Menurut Taylor, Lillis dan Le Mone (1997) aktivitas seksual yang sehat tergantung pada terbebasnya individu dari rasa bersalah dan ansietas. Apa yang diyakini salah oleh seseorang, bisa saja wajar bagi orang lain. Ada individu yang mengganggap ekspresi seksual tertentu dianggap tidak normal. Sebenarnya yang penting dipertimbangkan adalah rasa nyaman terhadap pilihan ekspresi seksual yang sesuai, yang hanya bisa dicapai apabila bebas dari rasa bersalah dan perasaan cemas.

Beberapa orang menganggap bahwa aktivitas seksual hanyalah berkutat pada urusan ranjang saja. Hal ini yang terjadi di kalangan masyarakat awam pada umumnya. Berbeda dengan kalangan orang yang mempunyai latar balakang medis, mereka lebih mengartikan aktivitas seksual adalah semua hal yang berkaitan dengan kehidupan seksual mereka (Sayekti, 2004).

\section{Konsep Diri Negatif}

Hasil penelitian menunjukkan bahwa penderita stroke merasa dirinya lemah dan tidak berdaya sehingga mereka mengungkapkan dengan istilah "sudah tua", "sudah lemah" untuk menutupi kekurangannya.

Konsep diri negatif dapat menyebabkan motivasi negatif yang akhirnya dapat mempengaruhi diri menghasilkan suatu tujuan 
yang kurang baik. Menganggap diri lemah menyebabkan partisipan menyebabkan motivasi yang rendah untuk melakukan aktifitas seksual.

Tingkat motivasi hidup penderita stroke tergantung dari sikap mental dan keadaan rohani penderita stroke. Jika penderita mempunyai motivasi yang positif maka penderita akan punya semangat untuk sembuh dan dapat menjalani hidupnya dengan baik dengan menjalankan kegiatan atau aktivitas seksual dengan baik. Sebaliknya jika motivasi negatif lebih mendominasi, maka penderita akan mengalami penurunan motivasi hidup.

Menurut Angeleri, et all. (1993), banyak faktor yang dapat mempengaruhi motivasi hidup penderita stroke, antara lain: (1) faktor ketidakmampuan melakukan aktivitas, dan (2) faktor lain seperti ketakutan mendapatkan kritikan dari orang lain atas kondisi fisiknya, depresi, kehilangan interaksi sosial, dan kehilangan kepercayaan diri atau merasa minder akan berdampak negatif terhadap motivasi hidup penderita.

\section{Keterbatasan Fungsi Seksual}

Hasil penelitian menunjukkan bahwa penderita stroke mengalami perubahan dalam aktifitas seksual akibat penyakit yang dideritanya. Keterbatasan fungsi seksual merupakan ketidakmampuan untuk melakukan aktifitas seksual yang disebabkan oleh malfungsi dari organ tubuh, seperti tidak berfungsi sebagai mana biasanya atau normal dan adanya kelemahan pada tubuh.

Penelitian yang dilakukan oleh Djeno (2005) menunjukkan bahwa terjadi perubahan perilaku seksual pada pria pasca stroke akibat adanya penurunan baik menurunkan libido, potensi seksual dan kepuasan seksual. Beberapa penderita pria dan wanita ragu untuk melanjutkan aktivitas seksual pasca stroke, karena takut bahwa akan menyebabkan suatu serangan stroke lagi.

Ketidakmampuan untuk melakukan activity daily living (ADL) secara mandiri merupakan salah satu faktor yang dapat menurunkan kualitas hidup penderita stroke, sehingga tidak jarang penderita stroke merasa tidak berguna dan merasa dikucilkan. Kondisi ini akan semakin diperparah jika keadaan rohaniah penderita stroke tidak kuat, akibatnya penderita mengalami depresi dan bahkan berusaha mengakhiri hidupnya (Ahlsio, et all, 1984).

\section{Faktor-faktor yang Mempengaruhi Aktifitas Seksual}

Hasil penelitian menunjukkan bahwa faktor fisik, budaya dan psikis mempengaruhi aktifitas seksual penderita stroke. Faktor fisik mempunyai peranan yang sangat penting dalam aktifitas seksual. Menurut Djeno (2005), faktor fisik yang berperan adalah pembuluh darah, hormonal, neuromuskular dan umur. Jika kondisi fisiknya dalam arti kesehatannya terganggu, seseorang kemungkinan besar akan mengalami gangguan pemenuhan kebutuhan seksualitasnya, yang dapat ditampilkan melalui berbagai aktivitas seksual. Seperti gangguan gerak, penurunan hormon yang menyebabkan menurunnya gairah seksual.

Faktor budaya, termasuk pandangan masyarakat tentang seksualitas dapat mempengaruhi individu penderita stroke. Tiap budaya mempunyai norma-norma tertentu tentang identitas dan aktivitas seksual. Menurut Jhonson (1989), budaya turut menentukan lama hubungan seksual, cara stimulasi seksual, dan hal lain yang terkait dengan kegiatan seksual. Pada kelompok etnis tertentu, wanita diharapkan untuk bersikap pasif dalam aktivitas seksualnya, sementara pada kelompok etnis yang lain, peran aktif wanita sangat dianjurkan. Dalam penelitian ini penderita pria lebih aktif daripada perempuan, seperti mengemukakan hasrat keinginan melakukan hubungan seksual dan posisi dalam aktifitas seksual yang didominasi pria sementara wanita bersipat pasif.

Faktor psikis sangat penting dalam melakukan aktifitas seksual. Faktor psikis meliputi perasaan seperti rasa cemas, malu, depresi dan konflik dalam hubungan pribadi. Penderita dengan psikis yang baik tidak akan takut melakukan aktifitas seksual, sebaliknya takut atau cemas jika terjadi sesuatu seperti takut hamil, nyeri, capai dan kekakuan.

Penelitian yang dilakukan oleh Djeno (2005) menunjukkan bahwa faktor psikis mempengaruhi aktifitas seksual pasien stroke. Jika psikis negatif mendominasi seperti depresi dan cemas menyebabkan rendahnya dorongan seksual.

\section{Fungsi Seksual}

Hasil penelitian menunjukkan bahwa aktifitas seksual dipengaruhi oleh fungsi seksual penderita stroke, yang terdiri dari dorongan seks (libido), rangsangan (arousal), orgasme, tingkat kepuasan, frekuensi seksual, dominasi dan posisi hubungan.

Dorongan seksual. Menurut Misbach (1999), dorongan seksual merupakan bentuk perilaku instingtif secara genetik terprogram dan 
tersimpan dalam sistem limbik dan hipotalamus. Dorongan seksual mutlak diperlukan, karena dialah energi awal yang membangkitkan fungsi seksual. Tanpanya, fungsi seksual tidak dapat berlangsung. Pada penderita stroke, diperlukan sentuhan, rangsangan dan pemanasan (foreplay) yang cukup agar dapat meningkatkan dorongan seksual. Penelitian yang dilakukan Djeno (2005) menunjukkan bahwa terjadi penurunan dorongan seksual pada penderita stroke.

Arousal. Menurut Misbach (1999), arousal atau rangsangan adalah meningkatnya reaksi seksual terhadap rangsangan seksual yang diterima. Manifestasi rangsangan pada pria berupa ereksi dan pada wanita berupa lendir vagina. Rangsangan pada penderita stroke dalam penelitian ini masih berfungsi dengan baik, tetapi kadang membutuhkan waktu yang lama. Hal ini sesuai dengan penelitian Djeno (2005) yang menemukan bahwa terjadi penurunan rangsangan pada penderita stroke.

Menurut Jhonson (1989), faktor-faktor yang mempengaruhi rangsangan adalah faktor hormon seks, psikis, keadaan kesehatan tubuh, dan pengalaman seksual sebelumnya. Bila semua faktor itu mendukung, maka akan berfungsi dan tetap bertahan, bahkan mungkin akan semakin membaik. Sebaliknya, bila faktor-faktor tersebut tidak mendukung, maka dorongan seksual akan menurun dan bahkan lenyap sama sekali. Pada penelitian ini arousal menurun karena faktor hormon, penyakit (diabetes) dan psikis (dihantui rasa takut terjadi nyeri saat kencing setelah melakukan hubungan seks).

Orgasme. Merupakan kenikmatan seksual yang merupakan puncak reaksi seksual. Puncak reaksi seksual tercapai bila menerima rangsangan seksual yang efektif. Jika orgasme tercapai akan dirasakan suatu sensasi erotik yang menyenangkan (Misbach, 1999). Pada penelitian ini penderita stroke masih mendapatkan orgasme tetapi membutuhkan waktu yang lama. Hal ini sesuai dengan penelitiannya Djeno (2005) yang menyatakan bahwa pada penderita stroke terjadi penurunan orgasme yang signifikan.

Tingkat kepuasan. Penderita stroke dalam penelitian ini sebagian besar mengalami penurunan tingkat kepuasan. Hal ini sesuai penelitian yang dilakukan oleh Djeno (2005) yang mengungkapkan bahwa $34,6 \%$ mengalami penurunan tingkat kepuasan. Begitu juga penelitian yang dilakukan oleh Kaperlein dkk. penurunan tingkat kepuasan mencapai 49\%. Menurut Hamid (1999), tubuh, jiwa dan emosi yang sehat merupakan persyaratan utama untuk dapat mencapai kepuasan seksual. Sakit, trauma atau stress dapat mempengaruhi kemampuan individu untuk melakukan kegiatan atau fungsi kehidupan sehari-hari yang tentunya juga mempengaruhi aktivitas seksualnya.

Frekuensi seksual. Penderita stroke dalam penelitian ini juga mengalami penurunan. Menurut Craven \& Hirnie (1996), aktivitas seksual manusia sangat beragam dan dipengaruhi banyak faktor. Faktor-faktor yang mempengaruhi aktivitas seksual antara lain aspek psikososial (emosional), dan biologik kehidupan, kondisi kesehatan, peran dan hubungan, kognitif dan persepsi, budaya dan nilai keyakinan, konsep diri, toleransi terhadap stress, serta pengalaman aktivitas seksual sebelumnya. Pendapat ini didukung oleh hasil penelitian Djeno (2005) yang mengungkapkan bahwa terjadi penurunan frekuensi hubungan seksual pada penderita pasca stroke sebesar 33,6\%. Begitu juga penelitian yang dilakukan Koperlainen sebesar $49 \%$, dan Monga 64\%. Dalam penelitian ini, frekuensi seksual berkurang karena psikis (trauma nyeri saat kencing dan ketakutan kalau terjadi hamil) serta perasaan ketidakmampuan melakukan hubungan karena merasa sudah lemah atau tua (fisik).

Dominasi dan posisi hubungan. Sangat dipenaguhi oleh faktor budaya, termasuk pandangan masyarakat tentang seksualitas dapat mempengaruhi individu. Tiap budaya mempunyai norma-norma tertentu tentang identitas dan aktivitas seksual. Budaya turut menentukan lama hubungan seksual, cara stimulasi seksual, dan hal lain yang terkait dengan kegiatan seksual. Pada kelompok etnis tertentu, wanita diharapkan untuk bersikap pasif dalam aktivitas seksualnya, sementara pada kelompok etnis yang lain, peran aktif wanita sangat dianjurkan. Pandangan agama tertentu yang diajarkan ternyata berpengaruh terhadap aktivitas seksual seseorang. Berbagai bentuk ekspresi seksual yang di luar kebiasaan, dianggap tidak wajar (Johnson, 1989). Dalam penelitian ini, dominasi dan posisi hubungan seksual dilakukan oleh penderita stroke pria. Begitu juga hasil penelitian Djeno (2005) yang mengungkapkan bahwa penderita stroke pria mendominasi aktifitas hubungan seksual. Menurut peneliti hal ini disebabkan oleh kultur atau budaya Indonesia.

Hasrat untuk Mengabdi. Hasil penelitian ini menunjukkan bahwa tujuan atau motivasi penderita stroke melakukan hubungan seksual adalah hasrat untuk mengabdi sebagai wujud mengaktualisasikan dirinya lewat pengabdian kepada pasangan dan dan Allah SWT.

Para penderita stroke masih mempunyai keinginan untuk memberikan kontribusi sebagai 
bentuk memenuhi tanggung jawab kepada pasangannya. Penderita stroke mengaku ingin melayani pasangannya. Selain itu penderita stroke berkeinginan untuk terus beribadah kepada Allah SWT dengan menjalankan perintah Nya. Ini menunjukkan bahwa kehidupan para penderita stroke dalam penelitian ini tidak bisa dipisahkan dari agamanya. Agama menyuruh kita menjalankan perintah Tuhan dan menjauhi perbuatan yang dilarang agama.

Menurut Soelaeman (2001) bahwa tugas hidup umat manusia adalah untuk beribadah kepada Nya, termasuk ibadah dalam arti khusus seperti pada shalat dan arti luas seperti berbuat baik terhadap sesama termasuk pasangan.

Tema tujuan atau motivasi di atas sesuai dengan konsep Faull \& Kalliath (2000), bahwa konsep spiritual akan diberi makna dengan karateristik hubungan individu dan hubungannya akan menentukan interpretasi mereka terhadap tujuan hidupnya. Termasuk dalam membangun konsep harapan, dimana fakta simboliknya seperti sikap positif dan penghargaan pada kehidupan secara umum.

Berhenti Melakukan Hubungan Seksual. Hal ini disebabkan oleh penyakit diabetes mellitus yang dialami oleh penderita. Menurut Jhonson (1989), beberapa penyakit yang menimbulkan gangguan hormon membuat gairah seks menurun karena gairah seksual ditimbulkan dan dipertahankan oleh hormon testosteron, dan bila hormon tersebut tertekan, maka akan mengakibatkan hambatan pada gairah seksual. Penyakit seperti kurang darah, gangguan penyerapan makanan, kadar gula dalam darah yang rendah, kadar kalium yang rendah, radang kelenjar prostat, kadang-kadang dapat juga menurunkan dan bahkan memadamkan gairah seksual. Hasil penelitian yang dilakukan oleh
Djeno 34,5\%, Monga 64\% dan Sjogren 41\% penderita pasca stroke berhenti melakukan hubungan seksual.

\section{SIMPULAN}

Berdasarkan hasil penelitian, diperoleh kesimpulan tema-tema perilaku aktifitas seksual adalah hubungan suami istri/ bersetubuh, konsep diri negatif, keterbatasan fungsi seksual, faktorfaktor yang mendorong aktifitas seksual, fungsi seksual, hasrat untuk mengabdi dan berhenti melakukan hubungan seksual. Perubahan perilaku aktifitas seksual penderita stroke dipengaruhi oleh kondisi penderita, agama yang diyakini dan budaya.

Saran untuk penelitian selanjutnya adalah: (1) sebaiknya peneliti melakukan survey terhadap demografi penduduk agar peneliti mempunyai data-data tentang para penderita stroke sebelum melakukan pengambilan informasi; (2) tingkat pendidikan partisipan sebaiknya setingkat atau lebih tinggi dari SLTA (Sekolah Lanjutan Tingkat Atas); (3) peneliti harus mempunyai keterampilan komunikasi yang bagus, dan memberikan pertanyaan terbuka, tidak memberikan pertanyaan tertutup atau pertanyaan yang mengarahkan suatu jawaban tertentu; (4) bukti fisik dalam bentuk video diperlukan untuk memberikan gambaran gesture dan bahasa nonverbal yang pada partisipan; (5) peneliti harus mempersiapkan dirinya dengan ilmu pengetahuan yang cukup, hal ini dilakukan dengan memperbanyak referensi sebelum menyusun proposal penelitian, peneliti harus mempunyai keterampilan komunikasi yang bagus dan mempersiapkan materi dan fasilitas penunjang agar pelaksaan pengumpulan data berjalan lancar.

\section{DAFTAR PUSTAKA}

Ahlsiö B., Britton M., Murray V., Theorell T., 1984. Disablement and quality of life after stroke. Stroke. 1984 Sep-Oct;15(5):886-90. http://www.ncbi.nlm.nih.gov/pubmed/6236 588

Angeleri F., Angeleri VA., Foschi N., Giaquito S., \& Nolfe S. 1993. The influence of depression, social activity, and family stress on functional outcome after stroke. Stroke. 24:1478-1483.

Asosiasi Herbalis Nusantara. 2011. Jumlah penderita stroke di Indonesia. Retrieved: 1 Februari 2012, dari http://www.herbalisnusantara.com/?

jumlah-penderita-stroke-diindonesia\% $\% 268$

Birkhead. 1989. Psyciatric/mental health nursing: The therapeutic use of self. Philadelphia: JB. Lippincott.

Craven R.F. \& Hirnie C.J. 1996. Fundamentals of nursing: Human health and function. Second edition. Philadelphia: J.B. Lippincott.

Djeno, S. 2005. Perubahan perilaku seksual pria pasca stroke. Tesis. Universitas Diponegoro. Tidak dipulbikasikan.

Hawari, D. 2003. Pendekatan Kejiwaan bagi Penderita Sakit. In Yafie, A., et al. (2003). 
Sakit menguatkan iman. Uraian pakar medis dan spiritual. Jakarta : Gema Insani Press.

Faull \& Kalliath. 2000. Handbook of Palliative Care. SecondEdition. India: Peplika. Pvt. Ltd.

Hafidz. 2006. Problematika Remaja S.O.S., http://www.slideshare.net/hafidz341/proble matika-remaja-sos-by-lds-dpphti, diakses tanggal 26 Maret 2013.

Hamid, A, Y. 1999. Aspek Psikoseksual dalam keperawatan. Jakarta: Widya Medika.

Jhonson, D. 1989. Teori Sosiologi Klasik dan Modern. Diterjemahkan oleh Robert M.Z. Lawang. Jakarta: Gramedia

Misbach J. 1999. Stroke, Aspek Diagnostik, Patofisiologi, Manajemen. edisi pertama, BP FK Universitas Indonesia, Jakarta.
Pangkahila, W. 2001. Seks yang Indah. Jakarta: Penerbit buku kompas.

Sayekti P. 2004. Berbagai Pendekatan Dalam Konseling. Yogyakarta: Menara Mass Offset.

Soelaeman, M. M. 2001. Ilmu budaya dasar suatu pengantar. Bandung : PT. Refika Aditama.

Taylor L, La Mone. 1997. Fundamentals of nursing: the art and science of nursing care B. Third Edition. Philadhelpia: Lippincott.

Taylor, Lillis C., dan LeMone. 1997. Fundamental of Nursing: The Art and Science of Nursing Care. Philadelphia: Lippinott-Raven Publishers.

Yastroki. 2007. Angka Kejadian Stroke Meningkat Tajam. Retrieved November 23, $2013 \mathrm{http}: / / w w w . y a s t r o k i . o r . i d ~$ 